\title{
Genetic aspects of conservation in farm livestock
}

\author{
C. SMITH \\ Dept. Animal Science, University of Nebraska, Lincoln 68583, U.S.A.
}

Concern about loss of genetic diversity in farm animals can be effectively met by storage of frozen semen or embryos. Genes may be stored in gene pools, but generally breeding stocks should be kept in pure form. Some other principles in conservation are ; 1) to store small samples of many stocks, 2) to choose diverse stocks, 3) to store stocks with special traits, and 4) to store locally adapted races (especially for developing countries). However, continuous genetic improvement in current stocks will make it increasingly difficult for unimproved conserved stocks to compete, unless there are reversals in breeding goals, or drastic changes in husbandry conditions.

\section{Les méthodes de conservation des gènes des animaux domestiques}

\author{
J.-P. RENARD \\ I.N.R.A., Station centrale de Physiologie animale, \\ F 78350 Jouy-en-Josas, France
}

Plusieurs méthodes permettent de conserver les gènes des animaux domestiques. La méthode des familles, et celles de groupes de reproduction, concernent les animaux vivants des races de petit effectif. La congélation des spermatozoïdes permet, sauf dans l'espèce équine, des taux de mise bas supérieurs à $50 \mathrm{p}$. 100. La congélation des ovocytes n'est pas encore applicable aux animaux domestiques. Par contre, la congélation des embryons se développe chez la vache, la brebis, la chèvre et la lapine ; elle n'est pas encore possible chez la jument, ni chez la truie. Le succès des programmes de conservation dépend des techniques, mais aussi de la volonté commune des éleveurs et des organismes publics.

\section{Organizational and psychological aspects of the conservation of animal genetic resources. Italian experiences}

\author{
G. ROGNONI *, A. FINCI **
}

* Istituto di Zootecnia, Facoltà di Veterinaria, Università di Milano

** Istituto di Zootecnia, Facoltà di Agraria, Università della Tuscia (Viterbo), Italia

In this paper are analysed the major factors to be considered in developing programs of defence of animal genetic resources and the principal causes of the success or failure of the programs carried out so far in Italy.

The organizational and psychological aspects are particularly emphasized. 